\title{
Mangurre Tarimbawo: An Exploration of Local Wisdom of Talaud Islands' Society in the Development of Character Education
}

\author{
$1^{\text {st }}$ Ruth Sriana Umbase \\ History Education Department \\ Universitas Negeri Manado \\ Manado, Indonesia \\ ruthumbase@unima.ac.id \\ $4^{\text {th }}$ Yohanes Burdam \\ History Department \\ Faculty of Social Science \\ Universitas Negeri Manado \\ Manado, Indonesia \\ yohanesburdam@unima.ac.id
}

\author{
$2^{\text {nd }}$ Revolson A Mege \\ Facullty of Mathemathics \\ and Science \\ Universitas Negeri Manado \\ Manado, Indonesia \\ ramege@unima.ac.id
}

\author{
$3^{\text {rd }}$ Aldegonda Evangeline Pelealu \\ History Education Department \\ Faculty of Social Science \\ Universitas Negeri Manado \\ Manado, North Sulawesi \\ aldegonda_pelealu@unima.ac.id
}

\begin{abstract}
This research aims to explore the values of "Mangurre Tarimbawo" which are contained in the local cultural wisdom of Talaud Islands' society. These values, among others, can be useful for the development of character education. The method used is Qualitative Descriptive Method. Research finding that "Mangurre Tarimbawo" which means pulling back the shackles off in order to release the shackles that break the ties of brotherhood and peace between the shackled parties (the troubled party), Talaud people have inherited from generation to generation, as one a form of reconciliation that is proactive. In the event of misunderstanding, wrong treatment, which can trigger conflict between individuals, or individuals with groups, or groups with other groups, the guilty party without being asked to feel obliged and responsible for restoring good relations that have been interrupted even disconnected, by reconciling through an apology and doing good in order to release the shackles that bind him so that peace is created without leveraging the mistakes and bad conditions that have occurred. By carrying out the "Mangurre Tarimbawo" the guilty party has retracted his wrongdoing and doing good deeds to please the party he has harmed. However, this tradition is slowly starting to have less influence along with various socio-cultural changes in younger generation, including a reduction in the use of local languages that provide deep meaning in the meaning and preservation of the values of local wisdom as a whole. Thus, a real effort is needed to explore the values of local wisdom that are useful to continue to be preserved in order to strengthen the socio-cultural arrangement as a basis for overall community development. One means of preserving culture is through formal, non-formal and informal education channels.
\end{abstract}

Keywords-Local Wisdom, Development of Character Education.

\section{INTRODUCTION}

The fact of the loss of a socio-cultural identity of a society is reflected in the loss of the values of local wisdom that become the living guide of that community. The loss of socio-cultural identity occurs because of the weakness even the failure of formal education institutions in schools, nonformal educational institutions in community and especially informal education institutions in the family in maintaining the values of local wisdom which actually has become the ancestral cultural treasures that should be studied and passed down through generations through these educational institutions.

Socio-cultural values that prioritize the formation of noble characters, gradually begin to be deemed not in accordance with the times, students are more be fond of the Popular Culture presented by various media available in the community. In fact, each region has cultural wealth that can be developed intelligently to become the basis for character education for students in that area. Along with the increasing technological advances in the field of games, there are various types of games that are very attractive and favored by students. Without realizing it, various types of modern games turned out to be full of character deterioration. Child character education is more dominantly shaped by what they enjoy in. Cunning characters, like to please themselves, like to win themselves, become idols because of their extraordinary abilities; even spiritism with miraculous power has hypnotized students to imagine themselves as formidable individuals, unbeatable with unparalleled magic power. Students whose personalities have been formed by cunning, arrogant, selfish, will be very difficult to be honest, humble, helpful, even willing to be fair and responsible. Furthermore, they are unable to see the beauty of character reflected by educators who have high 
discipline and are always firm in action. On the contrary, such an educator will be considered a bad and despicable person because he is considered rigid, orthodox and even considered "unsocial", likes to curb and does not understand the tastes of today's teens [1].

The problem of character education today has turn out so complex, the complexity of the problem, among others, comes from knowledge, awareness, exemplary, habituation, standards and integration of socio-cultural basic values in the process of educational in every educational paths. In the success of the character education process, [2] explained that there are eight steps or tips that can be done, they are understanding the nature of character education, socializing appropriately, creating a conducive environment, developing adequate learning facilities and resources, disciplining students, choosing a trustee headmaster, create a teacher who can be followed and imitated, and involve all school members in the success of character education. (2)

Nowadays the lack of knowledge, awareness and appreciation of the people for the values of character education which is based on the values of local wisdom is a worrying reality in the formation of noble characters. The facts about the lack of appreciation of the young generation towards traditional values which are actually full of local wisdom, need to be addressed seriously and a study of the factors that cause it.

In essence, character education moves from an awareness, understanding, caring, and commitment towards action [2]. [3] stated that the different thing was that character education was not limited to the transfer of knowledge about good values, but reached out to ensure that these values remained embedded and integrated in thought and action.

Awareness, understanding, caring and commitment to support character education in every educational path ideally emerge in each individual to build awareness of understanding, caring and commitment and collective action to synergy with each other.

In the identity contained local wisdom which is the result of Local Genius from various ethnic groups, this local wisdom should be knitted into a single cultural unit (Culture) to create a nation, called, the Indonesian Nation. Culture was born thousands of years ago since humans were on earth. The habits that have become and form human behavior are passed on from generation to generation. Culture itself is a product of human reason, at least when an etymological approach is taken. Culture in this case is called cultural very closely related to society. In this intergenerational culture rotation is needed a generation of intermediaries who are able to understand the older generation and are able to communicate into languages that are light and easily understood by the next generation [3].

Character education based on socio-cultural values including the values of local wisdom is effective in the character building process of students. Reference [1] explained that the socio-cultural values of the Minahasa community are effective in the development of character education in high school students in Minahasa, North Sulawesi, Indonesia.

In order for the existence of culture to remain strong, then the next generation and straightener struggle of the nation needs to instill a sense of love for local culture, especially in the region. One way that can be taken in school is by integrating the values of local cultural wisdom in the learning process, extra-curricular, or student activities at school. For example, by optimally applying Character Education Based on Local Cultural Wisdom [3].

Thus, efforts to awaken individuals and society to care and make commitments to preserve the values of local cultural wisdom that have been inherited by their ancestors can be one of the first steps to maintain the values of local wisdom as a source of content for learning material in character education.

\section{RESEARCH METHODS}

The research method used in this study is Qualitative Descriptive Research Methods. This research has been done in Salibabu Island, Talaud Islands in 2017. Data sources: indigenous elders who knew and played an important role in maintaining the customs of Inanguwanua (Chair/Customary Leader), Ratumbanua (Country Leader-Implementing Customary Decree), Timmadu Ruanganna (Chair of the Klan). Data Collection Technique: observation, interview, FGD. Data Analysis Techniques: Interactive. Data Validity Test: Credibility Test, Transferability Test, Dependability Test, Confirmability Test [4].

\section{RESULTS AND DISCUSSION}

The term of Mangurre Tarimbawo consists of two words Mangurre means withdrawing what has been given or done; Tarimbawo is a rope that shackles. In the etymological context of the structure of the Talaud language, this word if spoken in the context of action changes from mangurre tarimbawo to mangurren tarimbawo, which means activity or action to withdraw while breaking the rope that shackles itself and others in bonds that damage harmony and peace. The next act of reconciliation is to create a more harmonious reconciliation. Those who feel guilty are obliged and are responsible for making peace sincerely while doing actions that can please the parties who have been hurt. By creating such situations and conditions, both consider that all the bad or painful events in the past have been completed.

Mangurren Tarimbawo action is more often done in the context of resolving problems related to disruption of personal and social relations because of a disharmonies relationship or loss of peace due to misunderstandings, differences in opinion that lead to conflict.

The philosophical foundation of the life of the Talaud people revealed in the motto "Sansiote Sampate pate means 
Togetherness in One Unity" based from the values of local wisdom that are constantly strived to be preserved, among others, the value of Mangurren Tarimbawo which promotes a harmonious, peaceful and strong unity of live together. This strong bond is a joint task and responsibility under the leadership of the Timmadu Ruanganna (Chair of the Klan), Rantumbanua (Country Leader-Chairperson of the Customary Decree) and Inanguwanua (Chair / Customary Leader). Position and role of indigenous elders equal to each other and that differ between them is the duty and responsibility they have. Every decision taken is always based on consensus.

There is an interesting point from the position and role of traditional elders, which is the names of their respective positions which reflect very high respect for women, although in reality, it is rare for women to hold positions as traditional leaders at this time. The term for the position of chairman / country leader is called Inanguwanua means Mother Earth; Ratumbanua means the accompanying Queen of the Mother Earth (so, in the Talaud Islands in the days of the federal empire and then in the Dutch colonial era, a man who became a King was called the Queen while his queen was called Woi (Queen Woi or Queen Boki Woindatu). Other differences up to the 21 st century, even though there were no more royal governments but there were still many men named Queen and women named Boki, as a form of appreciation, respect, pride and love for boys and girls inside certain families, such as Queen Manongga, Queen Kantila, Queen Pese, Queen Wuatenna, Queen Matandatu, Queen Bee, and many other Queen names: Boki Ngello, Boki Pangare, Boki Setia, Boki Lembo Umbase and many other Boki names).

A person who bears the name of queen and woi/boki is expected to have the personality of a king and queen, namely the faithful, courageous, and a role model in respecting customs, especially in maintaining the values of local wisdom, knowing and being able to use local language in communication. Using Talaud language in communicating or talking among Talaud fellowship is still one of the criteria that the Talaud people still know the customs, and are not arrogant or humble.

Linguists argue that character education can be done through the use of polite language. For most Talaud people, the use of Talaud Language is a process of learning customs, traditions and culture. If the Talaud language with its various dialects is unknown and no longer used, then the Talaud community will become 'extinct'.

Based on the results of the discussion about the Mangurren Tarimbawo tradition, a number of values of local wisdom can be explored that can be useful to become material or learning material in character education, namely the value of affection (waakanna), maturity (masingkatu sinangngo), greatness of soul (naunga wahewa), humility (naunga mawawo), love of peace (mapulu madame), sincerity (maollaa surinone tawe mamunapikka), responsibility (manangguma) and harmony (wasasangkapianna) and friendship (magawe-pagaweanna) among fellow humans.

Regarding its application in character education, the role of teachers and parents is very important. [5] explained that there is an essential role in humans as a transmitter that receives and distributes character education energy through situations and conditions that influence students to do something based on a certain value.

Thus, the values contained in the local wisdom of the people in the Talaud Islands, especially the Mangurren Tarimbawo culture can be used as a reference in character education for students in the region. Even [6] in explaining local wisdom as a source of character education has emphasized that "the values of local wisdom can be used as a benchmark in acting and behaving and becoming an adhesive and identity of the community".

In character education there are various strategies, methods, techniques and tools that can be used in the learning process but one thing that cannot be ignored is the real practice in the daily life of students. [7] states that "the most important character education is done through habituation.". So, students not only learn to know, understand, analyze but do and get used to it. With habituation, the values that are used as references in character education will still exist and even become something to be proud of.

\section{CONCLUSION}

The values contained in Mangurren Tarimbawo are love, greatness of soul, humility, love of peace, sincerity, responsibility, and harmony and friendship. These values can be used as a basis for character education both in formal, non-formal and informal institutions for people in the Talaud Islands. The role of teachers and parents is very important to be an example in teaching and respecting the cultural values that have been owned by the community.

\section{ACKNOWLEDGMENT}

Thank you to the traditional leaders and the Talaud Islands community who have provided the information needed in this study, especially to Inanguwanua and Rantumbanua on Salibabu Island.

\section{REFERENCES}

[1] A. L. Lonto, "Pengembangan model pendidikan karakter berbasis nilai sosio-kultural pada siswa SMA di Minahasa," Mimbar, vol. 31, no. 2, pp. 319-327, 2015.

[2] E. Mulyasa, Menjadi Kepala Sekolah Profesional. Bandung: Remaja Rosda Karya, 2005.

[3] H. Houtman, "DIGITALISASI PEMBELAJARAN DAN PEMBENTUKAN KARAKTER SISWA BERBASIS 
KEARIFAN LOKAL,"WAHANA Didakt., vol. 15, no. 2, 2017.

[4] Sugiyono, Metode Penelitian Kualitatif, Kuantitatif dan $R \& D$.

Bandung.: Alfabeta, 2008.

[5] T. Suratno, "Memaknai Etnopedagogi Sebagai Landasan Pendidikan Guru di Universitas Pendidikan Indonesia," in Proceedings of The 4th International Conference on Teacher Education, 2010.

[6] A. L. Lonto and T. Pangalila, Etika Kewarganegaraan, 1st ed. Yogyakarta: Penerbit Ombak, 2013.

[7] Ferdinan Kerebungu, Implementasi Kurikulum. Jakarta: HISPISI. 